\title{
The Determinant Factors of Development Batik Cluster Business: Lesson From Pekalongan, Indonesia
}

\author{
SUPARNO $^{1}$, Agus WIBOWO ${ }^{2}$, Saparuddin MUKHTAR ${ }^{3}$, Bagus Shandy NARMADITYA ${ }^{4}$, Hikmah Diana SINTA ${ }^{5}$
}

Received: July 08, 2019 Revised: September 16, 2019 Accepted: September 30, 2019

\begin{abstract}
The study examines how business conditions, demand conditions and the role of government can influence the development of batik clusters in Pekalongan. This research is expected to be able to provide recommendations for both employers and local governments in order to help in optimizing the development of batik clusters. The research applied a quantitative research by engaging multiple regression analysis as an effort to understand the effect of the relationship between independent and dependent variables. In addition, this research was conducted in three largest batik clusters in Pekalongan, Indonesia namely batik cluster of Pasindon, Kauman, and Jenggot. These results indicate that business conditions positively affect the batik clusters development. It implies that the greater both business conditions in a cluster will lead the better the development. Indeed, the demand conditions also have an impact on the cluster development. This finding remarked that demand conditions are variable that need to be considered to development of batik cluster. Lastly, Government's role is confirmed that positively related to the Development of Batik Clusters. It implies that the more active the government's role in a cluster will have a good impact on the development of the cluster in certain area.
\end{abstract}

Keywords : Cluster Development, Business Conditions, Batik Business, Government Role, Indonesia

JEL Classification Code : M21, L21, R28

\section{Introduction}

The structure of the Indonesian economy has a considerable change in 1985. It was dominated by agricultural sector as the largest contributor of Gross Domestic Product (GDP). However, it showed a downward trend from year to year. It was approximately 31.4 percent in

1 First Author, Faculty of Economics, Universitas Negeri Jakarta, Indonesia. Email: suparno@feunj.ac.id

2 Corresponding Author, Faculty of Economics, Universitas Negeri Jakarta, Indonesia. [Postal Address: Gd. R, Faculty of Economics, Universitas Negeri Jakarta Kampus A, Jl. Rawamangun Muka, Jakarta Timur, DKI Jakarta, 13220, Indonesia]

Email: agus-wibowo@unj.ac.id

3 Faculty of Economics, Universitas Negeri Jakarta, Indonesia. Email: saparrudin@feunj.ac.id

4 Faculty of Economics, Universitas Negeri Malang, Indonesia. Email: bagus.shandy.fe@um.ac.id

5 Faculty of Economics, Universitas Negeri Jakarta, Indonesia. Email: hikmahdiana96@gmail.com

(c) Copyright: Korean Distribution Science Association (KODISA)

This is an Open Access article distributed under the terms of the Creative Commons Attribution Non-Commercial License (http://Creativecommons.org/licenses/by-nc/4.0/) which permits unrestricted noncommercial use, distribution, and reproduction in any medium, provided the original work is properly cited.
2014 , declined to the level of 28.53 percent in the next year, and only contributed about 23.89 percent in 2016 (Indef, 2015). In the beginning, it accounted for more than half of gross national production in Indonesia for agricultural sector, while the industrial sector contributed only 8 percent. However, in fact, at this time the manufacturing sector is the biggest contributor to GDP.

In 2014, the non-oil and gas processing industry was managed to contribute to GDP of 75.19 percent, and 63.70 percent in 2015. It means this sector accounts for more than half of the GDP (Bank Indonesia, 2015). The non-oil and gas processing industry sector includes textile and apparel industries and other industries. Even though, the textile industry on a national scale can only contribute less than 10 percent of GDP. However, from regional perspective with reference to industrial excellence in each region in Indonesia, some of them, such as Yogyakarta and Central Java Province have successfully provides textiles as their main stay industry including batik which is a local wisdom that is typical of Indonesia. For example, in Pekalongan in Indonesia, textile industry is one of the priority industrial sectors that will become most reasonable industry in the 
future.

The textile industry is currently in the $3^{\text {rd }}$ position of national exports and engaging the employment for more than 2.79 million people by obtaining production that is able to meet 70 percent of the domestic clothing needs. The Department of Industry and Trade of Pekalongan noted that in 2016 the export realization for the commodity reached USD 6,270,212 with a volume reaching out $748,261 \mathrm{~kg}$. In addition, throughout 2015, the textile sector has contributed 1.22 percent to the National GDP and an export surplus of USD 4.31 billion (Bank Indonesia, 2015).

The potential of Pekalongan batik industry is not only attracting investment but also known as one of the cities that contributes to the largest batik production in Indonesia. It is reasonable because the development of the batik industry in Pekalongan is definitely good compared to other batik producing cities such as Yogyakarta, Solo and Semarang in Indonesia. The development of batik encourages local governments to obtain in developing batik as one of the local economic potential that needs special attention. Due to this reason, the government in 2007 began promoting cluster systems in the batik industry sector, this was conducted to improve the development of the batik industry in Pekalongan (Alhusain, 2015).

The attempts of the regional government in the formation of batik clusters are certainly inseparable from various kinds of problems. In the development of clusters in Pekalongan shows that there are a number of factors that can influence the development of the batik industry cluster itself. Several factors that are predicted affecting of this development including of business conditions, conditions of demand, government interference, related industries and supporters, structure, competition strategy and cluster potential can influence the development of batik clusters to be better (Porter, 2000; Andriyanto \& Nurjanah, 2015).

The problems that faced in the cluster industry are in the scope of business conditions such as the quality of Human Resources (Bird \& Beechler, 1995). The low level of educational background tends to be difficult to be invited to cooperate both with fellow cluster members and batik entrepreneurs and suppliers (Susanty, Handayani, \& Jati, 2012; Puspaningrum, 2019). In addition, most of small-scale batik does not understand how to develop design and coloring technology that is tailored to market demand. Previous study on cluster development which carried out by Mirsa, Soetomo, and Asnawi (2016) in the Laweyan area in Indonesia. It remarked that the problems that can hinder the development of a cluster is the limited area of product marketing that affecting demand conditions and resulting in cluster growth.

In other hand, the demand condition also becomes the considerable aspects in the progress of a cluster (Mazur, Barmuta, Demin, Tikhomirov, \& Bykovskiy, 2016). When the demand conditions are on the positive side, the products that have been produced can generate profits, and vice versa. However, the problems that occur related to demand conditions are found in the ability of cluster industry players who are still low in their product marketing strategies. This condition can affect the level of demand for batik products produced. The problem is exacerbated by the influence of competitive strategy factors. It can be seen where domestic batik production often competes with imported batik products such as from China (Budiono \& Aryanto, 2010). It is because they are able to sell batik at lower prices compared to domestic batik production. This was feared would threaten the national batik industry.

For these matters, government also plays an important role to develop the government batik cluster. However, in fact the development of batik clusters in Pekalongan was considered to be lacking and not optimal yet (Susanty et al., 2012). Several clusters that are not able to survive will come out of the market, this is the obstacle in the effort to develop batik clusters in Pekalongan. The data from the Department of Industry, Trade and Cooperatives in the Pekalongan area, from 10 batik clusters in Pekalongan, its only three clusters have good development with a total production value of $11,428,130$, capable of absorbing 1,405 workers and having a total investment value of 1.9 billion in 2009. The government should pay attention to what factors will influence the development of batik cluster in order to optimize the development of the batik. Therefore, this study focuses on three factors that can influence the development of batik clusters, namely business conditions, demand conditions and the role of the government to understand which factors have the most influence in developing a batik cluster in Pekalongan.

\section{Literature Review}

\subsection{Cluster Development}

The development of cluster concepts was first put forward by Michael Porter in 1990 who argued that a cluster is a type of geographical concentration of a company or industry that is interrelated to establish a cooperative relationship. In addition, Majid (2005) remarked that development is an attempt to improve technical capabilities by paying attention to the potential that exists, while Wiryokusumo (2011) defines that development is an effort to grow, guide, develop a foundation of personality that is balanced, intact, harmonious, knowledgeable, skills in accordance with potential, desires and abilities, as a provision for one's own initiative to increase, enhance, develop themselves towards achieving optimal dignity, quality and human abilities and independent individual.

Marijan (2005) argued that industrial clusters are more viewed as a group of companies that are related to similar activities in a national economy rather than merely being located in a particular location. From those explanations, if the concept of development is associated with efforts to expand an industrial cluster, it is closely related to a systematic plan to seek improvement and quality 
improvement from several factors that can influence it such as business conditions that cover all matters related to production resources, demand conditions, business competition strategies, related industries and the role of the government.

Swords (2013) explained that there are six factors that play a role in increasing the competitiveness and development of a cluster, namely conditions, strategy, structure and competition between companies, factors in demand conditions, and related and supporting industry factors, the role of government and opportunities. Whereas according to Falkinger and Grossmann (2005) natural resources, labor, investment, entrepreneurship, transportation, communication, industrial composition, technology, size, export market, international economic situation, local government capacity, national expenditure and government spending and development supports.

Previous study by Muin (2013) mentioned five factors that influenced the development of Batik industry, namely financial management, capital, production, human resources and marketing. Similarly, Murti (2010) added the role factor of the government in enhancing cluster development. In addition, Ingstrup and Damgaard (2013) described eleven factors that were able to influence cluster development, including economic globalization, trade deficit, slower population growth and workforce, increased labor force participation by women, growth of high-tech industries and science-based economies/knowledge, excess production of commodity goods and industrial products, natural changes from the base economy, economic and corporate instability, increased competition and cooperation in the labor market, competition between business impulses and business climate, the importance of increased government and private cooperation.

\subsection{Business Conditions}

Oviatt and McDougall (2005) mentioned that business or company is to carry out activities permanently and continuously with the aim of obtaining profits, both those organized by individuals and business entities that are legal or not legal, which are established and domiciled in an area within a country. It is managed by individuals or groups that carrying out the economic activities to gain a profit. Business conditions other than regarding a situation or situation of a business or a company that continues to carry out production activities, business conditions also involve the basic requirements that must be owned by a business such as; location, raw materials, labor, science.

In addition, business unit is aimed to produce goods or services to be traded, and there are people who are responsible for managing the business, either by individuals or a household or a body and has authority determined based on the truth of the location of the physical building, and its operational area. Lauglo and Lilis (1988) named business unit or production with the term work. It is used for the purpose of producing goods and services that benefit the environment. The concept of business conditions is highly related to the situation of a business that is carrying out economic activities in the form of producing goods and services and distribution activities. In the process of activities requires a person or group of people who are authorized to manage the business to run smoothly.

Business conditions are closely related to the fulfillment of production resources or in economic terms are factors of production such as labor as someone who is authorized to manage business, raw materials, capital and technology for producing goods and many other factors. In more detail, some of the inputs needed to compete are human resources (HR), raw materials, technology, capital, location, production and others (Porter, 1990). Input conditions which are discussed by Porter (1990) have indeed become important aspects as a wheel to run a business. From those explanations, it can be concluded that the condition of the business is a situation that is being faced by a business unit, business entity or company that usually deals with production activities with the aim of gaining profit. The indicators of good business conditions can be seen from the quality of human resources, knowledge resources, capital, the availability of physical resources such as equipment and technology that can help the production process, then the location and location of the business and the quality of its products.

\subsubsection{Demand Condition}

The condition of demand with the success of a business is indeed inseparable. In general, demand is closely related to the relationship between the number of goods or services requested and the price of the goods themselves. For example, in a market there is a decline in demand conditions and cause the products that have been produced to be unsold, this will have an impact on the sustainability of the business itself. Therefore it is important for business people to understand more deeply the concept of demand itself. According to Soeharno (2007) demand is various quantities of goods which consumers are willing to pay for various alternative goods. This opinion is reinforced by Mankiw (2004) which mentioned that demand as consumer behavior in buying a particular type of goods and services.

Rahardja and Manurung (2014) in more clearly, the demand explains the characteristic of the relationship between the number of demand and prices. In economics, the term demand has a certain meaning, that is, it always shows a certain relationship between the amount of goods that consumers want to buy and the price of the item. The concept of demand in essence is a description of the ability of consumers in buying an item at various price levels and at a certain time period. The good demand conditions can be seen through several indicators such as; the existence of demand sources, the good number of requests for products produced, and the existence of good market and product development. 


\subsubsection{The Role of Government}

The role of the government in seeking progress and welfare of its people is one of the important points that must be considered (Curristine, Lonti, \& Joumard, 2007). Sastropoetra (1986) role definition is as spontaneous involvement that is accompanied by awareness and responsibility towards the interests of the group to achieve common goals. Based on the opinion, the definition of role is the action or action of someone who is involved in certain events both between individuals and groups carried out with awareness and accompanied by a sense of responsibility.

The role definition is essentially an active involvement, participation and participation in decision making in accordance with the position in which he is attached. Furthermore, the concept of the government itself is the authoritative direction and administration of the affairs of men/women in a nation state, city and so forth. The form of the role of government in the government household is to provide services, empowerment and development to achieve a welfare and social justice for all people. The indicators of the good or bad role of government in a region can be seen from the availability of good infrastructure, providing real assistance, and making policies that support the existence of clusters.

\section{Research Methods and Materials}

The study applied a quantitative method using multiple regression in order to predict the influence between independent variables which is business conditions, demand conditions and the role of the government and dependent variables, namely the development of batik clusters. Furthermore, the data collection technique in this study is a survey through a questionnaire of 38 questions by asking for an assessment of 78 respondents for the existence of these factors by choosing an attitude of agreement using Likert Scale. The research analysis technique used descriptive analysis techniques and inferential analysis. The population in this study is all batik clusters in the Pekalongan in Central Java of Indonesia. The population in this study was spread in three batik clusters in Pekalongan namely batik cluster Pasindon, Kauman, and Jenggot. These three clusters were chosen because they are the largest batik cluster in the Pekalongan area. Therefore, it is expected to be able to present the results of research. Meanwhile, the sample is the part of the number and characteristic of the population. In this study the respondents were 26 SMEs joined in the Pasindon Batik Industry Cluster, 26 SMEs joined in the Kauman Batik Industry Cluster, and 26 SMEs joined in the Batik Jenggot Industrial Cluster. Taking the number of cluster samples that are the object of this study refers to the Slovin formula.

\section{Research and Discussion}

Validity test shows every R-count $\geq 0.22$ then the reliability test shows that each variable has a Cronbach Alpha value $\geq 0.60$. Thus each instrument item is valid and trustworthy. Based on the Normality Test it is known that the significance value of the government's role is 0.451 ; demand conditions 0.488; business conditions 0.955 and cluster development 0.252 . Of the four variables have a significance value greater than 0.05 therefore it can be concluded that the data is normally distributed. Based on the Linearity Test the values from Linearity for $\mathrm{X}_{1}$ and $\mathrm{Y}$ are $0.156 ; \mathrm{X}_{2}$ and $\mathrm{Y}$ are $0.736 ; \mathrm{X}_{3}$ and $\mathrm{Y}$ are 0.685 . Therefore, it can be interpreted that if the three output values are greater than 0.05 then the data has a linear relationship. The calculation of multiple regression result using SPSS.18 is presented in Table 1.

Table 1: Multiple Regression Test

\begin{tabular}{|l|c|c|c|c|c|c|}
\hline \multirow{2}{*}{ Model } & Dependent variable & \multicolumn{2}{c|}{ Independent Variables } & \multirow{2}{*}{ F } & \multirow{2}{*}{ R Square } \\
\cline { 2 - 5 } & Constant & $\mathbf{X 1}$ & $\mathbf{X 2}$ & $\mathbf{X 3}$ & \\
\hline Coefficient & 1.742 & 0.094 & 0.375 & 0.358 & 134.985 & 0.845 \\
\hline SE & 1.177 & 0.043 & 0.091 & 0.128 & & \\
\hline t-test & 1.481 & 2.206 & 4.112 & 2.799 & & \\
\hline sig & 0.143 & 0.03 & 0.000 & 0.007 & & \\
\hline
\end{tabular}

Based on Table 1, the multiple regression equation is obtained as follows:

$$
\mathrm{Y}=1.742+0.094 \mathrm{X} 1+0.375 \mathrm{X} 2+0.358 \mathrm{X} 3
$$

It implies that if the Business Conditions $\left(\mathrm{X}^{1}\right)$, Demand Conditions $\left(\mathrm{X}_{2}\right)$, and Government $\left(\mathrm{X}_{3}\right)$ have a value of 0 , then the Cluster Development (Y) value is 1.742. The coefficient value of $\mathrm{X}_{1}$ of 0.094 points has meaning if the Business Condition $\left(\mathrm{X}_{1}\right)$ increases by 1 point, then Cluster
Development (Y) will also increase by 0.094 points in the constant of 1.742 , noting that the coefficient values of $\mathrm{X}_{2}$ and $X_{3}$ remain. The positive coefficient of $X_{1}$ means that there is a positive influence between Business Conditions and Cluster Development which indicates that the more the Business Condition increases, the Cluster Development will also increase. The coefficient value of demand condition is about 0.375 means that if the Demand Condition $\left(\mathrm{X}_{2}\right)$ increases by 1 point, the Cluster Development (Y) will increase also by 0.375 points in the constant of 1.742 , noting 
that the coefficient values of $X_{1}$ and $X_{3}$ remain. The positive coefficient of $\mathrm{X}_{2}$ means that there is a positive influence between the Demand Condition and the Cluster Development which indicates that the Increasing Demand Condition increases the Cluster Development.

Coefficient value of Government is 0.358 and has a meaning if the Government increases by 1 point, then Cluster Development $(\mathrm{Y})$ will also increase by 0.358 points in the constant of 1.742 , noting that the coefficient values of $X_{1}$ and $X_{2}$ remain. The coefficient of $X_{x}$ is positive, meaning that there is a positive influence between the Government and the Cluster Development which indicates that the Government is increasing, the Cluster Development is also increasing. There are conceptual models in the research described in Figure 1.

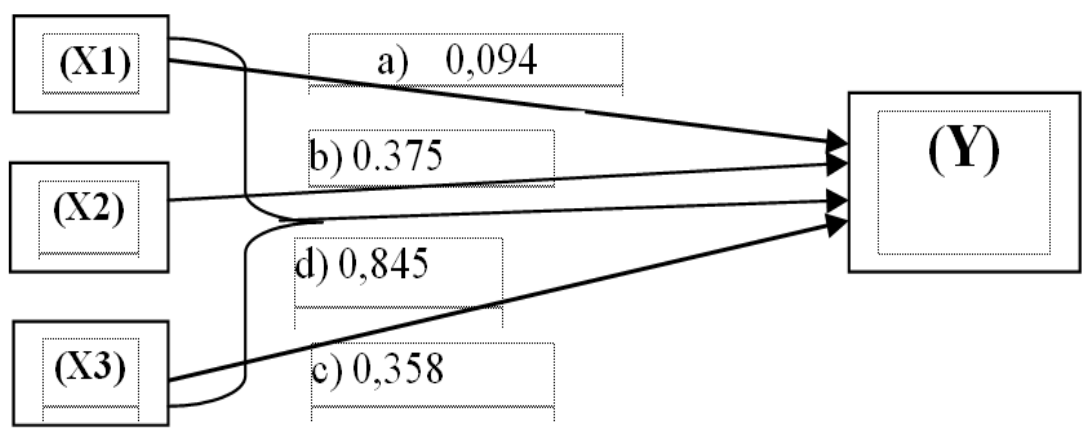

Figure 1: Conceptual Research Model

Information:

$\mathrm{X}_{1}=$ Business Conditions

$\mathrm{X}_{3}=$ Government Role

$\mathrm{X}_{2}=$ Request Condition

$\mathrm{Y}=$ Cluster Development

\subsection{The Direct Effects of Business Conditions on Cluster Development}

The results of this study indicate that business conditions have a direct positive effect on cluster development, it was found through data analysis with a coefficient of 0.094 or equivalent to 9.4 percent. The factors of business conditions are most influenced by capital indicators, which are equal to 25.43 percent. Therefore, the provision of capital to encourage business conditions needs to be carried out with the support of other indicators that are in the business conditions such as; quality of human resources (HR), increased knowledge resources, improved product quality, fulfillment of physical resources and good location placement.

This finding is in line with previous research conducted by Susanty et al. (2012) which stated that these factors indicate the position of a cluster in production factors. In addition, business conditions are one of the factors that are indispensable as a basic fuel to create a cluster with good development. Indeed, this study supports prior study conducted by Muin (2013) which mentioned that development is a process to grow or expand a cluster using certain factors such as designing financial management, capital, production, human resources (labor) and marketing. In more detail, from these five factors, four of them are included in the indicator of the business conditions. Then, it can be concluded that there is an influence between Business Conditions and Cluster Development. Thus, the higher the level of business conditions, the better the effort to improve the development of a cluster.

\subsection{The Direct Effects of Demand Conditions on Cluster Development}

The findings of this study indicate that the Demand Condition has a direct positive effect on cluster development, it was found through data analysis with a coefficient of 0.375 or equivalent to 37.5 percent. Therefore, efforts to increase the number of requests or at least stabilize the demand for batik products produced need to be considered. In addition, in order to encourage the condition of good demand in a cluster, it needs to be supported by other indicators in the factor of demand conditions such as an increase in sources of demand both at home and abroad and business development of markets and products.

This research is in line with research conducted by Susanty et al. (2012) which stated that the growth/development of a batik cluster in the Kauman and Jenggot areas is influenced by the presence of demand conditions. The market development indicators are the most influential on the Demand Condition Factors; whereas, in the Beard Industry Cluster, demand of sources are the most influential on Demand Condition Factors (Susanty et al., 
2012). Therefore, it can be said that there is a significant positive direct effect between the demand conditions and cluster development. Based on the explanation, it can be concluded that there is a positive direct influence between the request conditions for cluster development. It implies that the better the conditions of demand that exist in the cluster.

\subsection{The Direct Effects of the Government's Role on Cluster Development}

The results of this study indicate the role of the government has a direct positive effect on cluster development, it was found through data analysis with a coefficient of 0.358 or equivalent to 35.8 percent. Where the factor of the Government's Role is most influenced by policy indicators, namely 33.72 percent. Therefore, the government's efforts to create policies that support cluster existence are very necessary to be carried out with the support of other indicators that are in the role of the government, such as providing real assistance to in a cluster and proper infrastructure improvements.

This finding is in line with the research that was proposed by Handayani, Prastawa, and Fithriana (2014) which mentioned that greater participation of the government will lead to the greater the potential for cluster development. Based on the findings, it can be known that there is a positive direct influence between the government's Role on Cluster Development. Thus, the better the government's role in the existence of a cluster. In addition, there is also increasing (good) development of a cluster in the area.

\subsection{The Direct Effects of Business Conditions, Demand and Government Conditions on Cluster Development}

The results of this study indicate that Business Conditions, Demand Conditions and Government have a direct positive effect on innovation found through data analysis with a coefficient of 0.845 . This research is in line with Porter (1990) which reveals that there are several factors that play a role in the development of a cluster in an effort to increase competitiveness, including: There are six factors that play a role in increasing the competitiveness and development of a cluster namely Business Condition Factors, Structural Strategy and Competition Factors between companies, Demand Condition Factors, Related Industries and Supporters, Government Roles and Opportunities.

From this findings, it that can be drawn from the theory of the development of a cluster that was put forward by Porter if we look in detail will be divided into two, namely internal factors such as Business Conditions Factors, Structure and Competition Strategy Factors between companies, Factors of Demand Conditions, Related Industries and supporters. Then two of them, namely the
Role of the Government and Opportunities, are external factors that both affect the business in developing an industrial cluster. Thus it can be said that there is an influence between Business Conditions, Demand Conditions and the Role of the Government on the Development of a Cluster, where the three factors are part of the factors mentioned by Porter (1990)

Based on the previous explanation and strengthened by the results of the calculation of the degree of simultaneous influence in this study which amounted to 0.845 or equivalent to 84.5 percent. Then, it can be concluded that there is a positive direct influence between Business Conditions, Demand Conditions, and the government on Cluster Development. Thus, the better (higher) Business Conditions, Demand Conditions and the Government's Role, the better (good) development of a cluster will be. While the remaining 15.5 percent is influenced by other variables not examined.

\section{Conclusions}

The main concerns Based on the results of data analysis can be drawn several conclusions: First, there is a positive and significant influence between Business Conditions and Development of Batik Clusters in Pekalongan, meaning that the better the condition of business conditions in a cluster, the better the development of the cluster. In addition, there is a positive and significant influence between the Conditions of Demand and Development of Batik Clusters in Pekalongan, meaning that the better the conditions of demand in a cluster, the better the development of the cluster will be. Further, Government's Role positively related to the Development of Batik Clusters in Pekalongan. It implies that the more active the government's role in a cluster will have a good impact on the development of the cluster. Lastly, there is a simultaneous influence between Business Conditions, Demand Conditions and the Government's Role on the Development of Batik Clusters in Pekalongan. This means that the better the business conditions, the conditions of demand and the active role of the government in a cluster.

\section{References}

Alhusain, A. S. (2015). Kendala dan Upaya Pengembangan Batik di Surakarta Menuju Standarisasi. Jurnal Ekonomi \& Kebijakan Publik, 6(2), 199-213.

Andriyanto, I., \& Nurjanah. (2015). Strategi Klaster Industri Menghadapi Pasar Global. Journal of Islamic Business and Management, 3(1), 105-109. DOI: http://dx.doi.org/10.21043/bisnis.v3i1.1474.

Bank Indonesia. (2015). Laporan Perekonomian Indonesia 2015. Retrieved August 30, 2019, from https://www.bi.go.id

Bird, A., \& Beechler, S. (1995). Links between business 
strategy and human resource management strategy in US-based Japanese subsidiaries: An empirical investigation. Journal of International Business Studies, 26(1), 23-46.

Budiono, G., \& Aryanto, V. (2010). Batik industry of Indonesia: Rise, fall and prospects. Studies in Business and Economics, 5(3), 156-170.

Curristine, T., Lonti, Z., \& Joumard, I. (2007). Improving public sector efficiency. OECD Journal on Budgeting, 7(1), 1-41.

Falkinger, J., \& Grossmann, V. (2005). Distribution of natural resources, entrepreneurship, and economic development: Growth dynamics with two elites (Cesifo Working Paper No. 1562).

Handayani, N. U., Prastawa, H., \& Fithriana, M. H. (2014). Faktor-Faktor Yang Mempengaruhi Potensi Pengembangan Klaster Industri Batik Lasem di Kabupaten Rembang. Prosiding SNST Fakultas Teknik, 1(1), 7-12.

Ingstrup, M. B., \& Damgaard, T. (2013). Cluster facilitation from a cluster life cycle perspective. European Planning Studies. 21, 556-574.

DOI: $10.1080 / 09654313.2012 .722953$.

Indef. (2015). Proyeksi Ekonomi Indonesia 2015: Tantangan Kabinet Kerja Memenuhi Ekspektasi. Jakarta, Indonesia: Indef.

Lauglo, J., \& Lilis, K. (1988). Vocationalization in international perspective. Oxford, England: Pergamon Press Headington Hill Hall.

Majid, A. (2005). Learning planning. Bandung, Indonesia: Rosdakarya.

Mankiw, G. N. (2004). Introduction to microeconomics. Jakarta, Indonesia: Salemba Empat.

Marijan, K. (2005). Mengembangkan Industri Kecil Menengah Melalui Pendekatan Kluster. Insan, 7(3), 216225.

Mazur, V. V., Barmuta, K. A., Demin, S. S., Tikhomirov, E. A., \& Bykovskiy, M. A. (2016). Innovation clusters: Advantages and disadvantages. International Journal of Economics and Financial Issues, 6(1S), 270-274.
Mirsa, R., Soetomo, S., \& Asnawi, A. (2016). Spatial settlement pattern of settlements in Laweyan as supportive batik production activities. Indonesian Journal of Geography, 48(1), 84-90.

Muin, A. (2013). Faktor yang Mempengaruhi Pengembangan Klaster Batik Laweyan-Surakarta Menuju Ekonomi Lokal Berkelanjutan. Jurnal Wilayah dan Lingkungan, 1(1), 79-90.

Murti, A. I. (2010). The role of regional government in developing Laweyan batik cluster. Tataloka Journal, 12(1), 55-62.

Oviatt, B. M., \& McDougall, P. P. (2005). Defining international entrepreneurship and modeling the speed of internationalization. Entrepreneurship Theory and Practice, 29(5), 537-553.

Porter, M. E. (1990). The competitive advantage of nations. New York, NY: The Free Press.

Porter, M. E. (2000). Location, competition, and economic development: Local clusters in a global economy. Economic Development Quarterly, 14(1), 15-34.

Puspaningrum, A. (2019). Factors affecting the development of small and medium industry business in Malang City. Jurnal Aplikasi Manajemen, 17(2), 328-335.

Rahardja, P., \& Manurung, M. (2014). Teori Ekonomi Mikro: Suatu Pengantar. Jakarta, Indonesia: UI Press.

Sastropoetra, R. (1986). Community participation in planning decision making in schools. Yogyakarta, Indonesia: Student Library.

Soeharno, T. S. (2007). Teori Ekonomi Mikro. Surakarta, Indonesia: Penerbit Andi.

Susanty, A., Handayani, N. U., \& Jati, P. A. (2012). Analisis Faktor-faktor Yang Mempengaruhi Pertumbuhan Klaster Batik Pekalongan (Studi Kasus Pada Klaster Batik Kauman, Pesindon Dan Jenggot). Rekayasa, 5(1), 1-13.

Swords, J. (2013). Michael Porter's cluster theory as a local and regional development tool: The rise and fall of cluster policy in the UK. Local Economy, 28(4), 369-383.

Wiryokusumo, I. (2011). Konsep Dasar Pengembangan Kurikulum. Jakarta, Indonesia: Rineka Cipta. 